Jurnal Akuntansi dan Investasi, Vol. 19 No. 1, Hlm: 64-75 Januari 2018

Artikel ini tersedia di website: http://journal.umy.ac.id/index.php/ai

DOI: $10.18196 /$ jai.190192

\title{
The Effect of Ownership Structure and Investor Protection on Firm Value: Analyst Following as Moderating Variable
}

\author{
Desi Susilawati and Fuad Rakhman* \\ Vocational Program Universitas Muhammadiyah Yogyakarta, Yogyakarta, Indonesia \\ Faculty of Economics and Business Universitas Gadjah Mada, Yogyakarta, Indonesia
}

\begin{tabular}{l}
\hline A R T I C L E I N F O \\
\hline Article history: \\
received 21 Jul 2017 \\
reviwed 04 Aug 2017 \\
revised 19 Dec 2017 \\
accepted 19 Dec 2017
\end{tabular}

Keywords:

Concentrated

Ownership; Analyst

Following; Investor

Protection; Firm Value

\begin{abstract}
The research related to the association between structure ownership and the firm value is a discussion about corporate governance which is still has contradictory conclusion and mixed result. It indicates open question that needs empirical evidence. The influence of concentrated ownership on firm value still brought conflict of interest so the role of analyst following can be stated as an alternative of corporate governance mechanism (Lang et al., 2004). The objectives of this research are to examine the interaction effect between concentrated ownership and analyst following, and the effect of investor protection toward firm value in five Asian companies. Asia is chosen because it has unique characteristic, in term of corporates ownership structure which is more concentrated on families and board of governance is weak (Choi, 2003). The data is consisting of 7.100 firm year observations obtained from Bloomberg and OSIRIS database for the period 2011-2013 in five Asian Countries, i.e. China, South Korea, Malaysia, Taiwan, and Thailand. Multiple Regression analysis is used to test hypotheses. The results show that concentrated ownership is positively affects the firm value. However, there is no empirical evidence that the interaction of concentrated ownership and analyst following positively affect the firm value. As hypothesized, this research also shows that investor protection has negative impact on firm's value.
\end{abstract}

(C)2018 JAI. All rights reserved

\section{INTRODUCTION}

The research that is related to the association between ownership structure and firm performance is a discussion that still raises conflict between managers and owners of companies or shareholders. Several previous research results show a contradictory conclusion about the association between ownership structure and firm performance. Shleifer and Vishney (1986) used sample of 456 companies, stating that concentrated ownership positively affects the firm performance. Shah and Hussain (2012) used a sample of 61 non-financial firms listed on the Karachi Stock Exchange to examine the effect of ownership structure and concentrated ownership structure on firm value. However, the results of the research indicate that the ownership is concentrated on the managerial, which means that the increasing share portion owned by the managerial party has an impact on the negative relationship with firm value while concentrated ownership shows insignificant influence.

This positive impact can be explained that the majority owners or blockholders have the power to supervise the managers in running the firm's operations for the benefit of the shareholders. Demsetz and Lehn (1985) provide evidence that concentrated ownership is positively related to potential supervisory activities performed by the owners of capital. The higher the share ownership, the supervision of the majority shareholder will also be higher, so the value of the company will also increase (Smith, 1996).

Fama and Jensen (1983), and Pedersen and Thomsen $(1997,1999)$ state otherwise that concentrated ownership negatively affects firm performance. Lemmon and Lins (2003) conducted a research using a sample of 800 firms in the emerging markets in eight East Asian countries. The results stated that concentrated ownership had a negative effect on the firm value. La Porta, 2000 describes that this negative impact 
is because of the likelihood that the majority owners of controlling shareholders are strongly motivated to make "unfair" transacttions to divert company resources to increase their own prosperity. The information asymmetry approach is a way to reduce the imbalance of information disclosure in capital markets between internal and external parties (Shah and Hussain, 2012). The results of analytical activity in the form of analyst following are expected to reduce the imbalance of information disclosure in the capital market between internal and external parties.

Financial analysts can play a role in reducing agency costs that arised because of the separation of ownership and supervision called security analysts. The analysts play a role through two mechanisms, as a monitor and as an information mediator (Cheng and Subramayam, 2008). Analysts as the monitor have the sense that they supervise the actions of managers and publish the manager activities. The second role of analysts is that as a firm information intermediary has the sense that the analyst as a bridge of information between internal and external firms to reduce the risk of information asymmetry. McConnell and Servaes (1990) documented empirical evidence that analyst following have a positive effect on the firm value. The analysts have the potential to improve the quality of information and therefore it is able to reduce the uncertainty, reduce the risk of information asymmetry, and is expected to increase the market value.

Lang et al. (2003) states that the greatest supervision rights are in the family or governance group (the largest blockholders), resulting in a decreasing number of analysts following. The analysts are less interested in firms with poor firmlevel corporate governance, such as concentrated ownership. This is further reinforced if the firm is domiciled in a country with law protection against low investors, so the role of analysts is more effective in countries with advanced capital markets and high investor protection.

This research examines the interaction between analyst following and the concentrated ownership structure to the firm value. Analyst following has a positive effect on the firm value which means that although the company has a high concentrated ownership but the analysts continue to analyze the firm and therefore it will give a positive impact on the value of the firm. This provides benefits to the investors and thus affects their decisions.
Highly concentrated ownership has consequences of minority shareholders. The need for investor protection will be higher if there is a minority shareholder (Boubaker and Labegorre, 2008). The protection of minority investors is weaker if the investor's ability to supervise the governance is weak. The role of analysts as monitoring and information intermediaries can provide protection especially information protection and therefore it is expected to reduce the information gap to minority shareholders. This indicates that the role of analysts will increase, especially in countries with low investor protection (Lang and Lundholm, 1996).

Analyst following can give a positive impact for firms with low governance. Firms that have low governance but has more number of analysts who examine the firm will have a positive impact on firm value (Yu, 2009). Lang and Lundholm (1996) state that with the role of analyst following can increase the investor knowledge, reduce information asymmetric risk, and reduce capital costs. This research examines the impact of interaction between concentrated ownership and analyst following to the firm value.

This research is different from Lang et al. (2004) and Chang et al. (2000), which show that (1) the sample selection are from firms in five Asian countries and firm sample of each country are in larger quantities, so it is expected to reflect more on the condition of the country, (2) in general, the capital market in Asia is the emerging capital market and therefore the information environment is different from the developed capital market.

The analysts have incentives to be active in conductiong its function as independent supervisors which can only be tested in common law countries with strong investor protection (Barniv et al., 2005). In connection with this statement, the question arises on how are the role of the analysts if testing is conducted in the code law country with low investor protection and a little hindrance for the internal firms to exploit the firms' wealth. Further motivation as far as the best knowledge of the researcher, there is still little literature that discusses the relationship between the firm value and analyst following on different spheres of governance and law enforcement. One of the reasons is that the limited data related to analyst following in emerging market. This research is expected to attract the attention of the analysts to analyze the firm's financial data in emerging market. The choice of Asian firms as research 
samples is because most Asian firms have a concentrated ownership structure, which have the potential to experience greater agency issues related to governance, and tends to be a country with low investor protection.

Based on the background explained, this research specifically aims to test: (1) the influence of concentrated ownership and firm value, (2) the interaction between analyst following with ownership structure to the firm value, and (3) the influence of investor protection to the firm value. This research contributes to three important things: (1) deeper understanding of the effect of concentrated ownership on the firm value and how the interaction effects between the concentrated ownership structure with the analyst following to the firm value; (2) strengthening the literature on the role of analysts in balancing information between internal and external parties of the firms, especially the emerging capital markets in the Asian region; and (3) strengthening the argument that the investor protection environment plays a role in determining the firm value. The researcher expect that the role of the analysts would be more effective as an independent monitor (Healy and Palepu, 2003) since the recommendations given are more useful to the investors if there is an analyst following in a firn with low corporate governance and located in a country with low investor protection.

This research consists of 5 sections. Section 2 in this research contains of literature review and hypothesis development. Section 3 describes the research design, which consists of sample selection, operational definitions of variables and statistical testing tools used. Section 4 describes the results of the research and section 5 presents the conclusions and limitations of the study.

\section{LITERATURE REVIEW AND HYPOTHESIS DEVELOPMENT}

\section{Agency Theory}

The Agency Theory is presented by Jensen and Meckling (1976) who state that the perception of governance relationship as a contract between the principal and the director. Both relationships are assumed that both parties are utility maximizers so it is reasonable to say that agents do not always act on the best interest principal. Agency theory states that the two parties that do contract are in the condition of information asymmetry because the agent has more information about the firm than the owner of the capital. This can lead to a conflict of interest between the two parties with the assumption of underlying the theory that each individual will act in order to maximize their own interests.

\section{Corporate Governance Theory (CGT)}

CGT is presented as the underlying theory of researches that discuss ownership structures and the relationship between capital owners and agents. Giilian (2006) classifies corporate governance into two groups, namely internal corporate governance and external corporate governance. Gillian divides internal corporate governance into 5 basic categories: 1) The Board of Directors (2) Managerial Incentives, 3) Capital Structure, 4) Bylaw and Charter Provisions, and 5) Internal Control System. Corporate Governance Mechanism in the form of information about the board of directors is the most accessible information by investors.

Claessens et al. (2000) explains that most companies in East Asia have a concentrated ownership structure with supervision and control lying in that majority group. Firms in Asian countries have lower internal governance levels such as lower board independence and relatively have incomplete committees. Most countries in Asia that are in a state of weak legal system and protection of weak investors is called code law. Countries that are included in the category of code law groups are China and South Korea. Countries with common law legal systems have strong investor protection (La Porta et al., 1998). Compared to countries in Southeast Asia, East Asian countries such as China, Japan, Hong Kong, and Korea have more developed economies. The advanced economic conditions and market conditions have led to the creation of strong investor protection. However, there are some countries in Southeast Asia that belong to the Common Law group of countries, such as Taiwan, Malaysia, and Thailand.

Ownership structure is one of the dimensions of corporate governance that is believed to affect the performance of the firm in which also affects the relationship between the owners of capital with agents. High concentrated ownership structures have the potential to raise the agency issues and tend to manipulate the information because there is an increased intervention from the majority shareholder. A control which is mostly held by a 
few parties can lead to higher agency problems, while Taiwan, Malaysia and Thailand are common law countries with low investor protection.

\section{Concentrated Ownership Structure and Firm Value}

The results of research related to the relationship between the concentrated ownership structures with the firm value is still contradictory. The result of testing the relationship between the concentrated ownership structure and firm value is not yet conclusive in which there are two contradictory conclusions and therefore further empirical testing is required. Some researches show that there is no monotonous relationship between ownership structure and firm performance (Morck et al., 1988). In contrast, La Porta (2000) states that there is a negative influence between the concentrated ownership structure and the firm value. This negative impact is due to the possibility that the majority owners of controlling shareholders are strongly motivated to make "unfair" transactions to divert the firm resources to increase their own prosperity.

Increasingly concentrated ownership can improve a firm's supervision function. If the shareholder of a firm is owned by a small portion of the party, it can create a self-monitoring function to enhance the managerial accountability (Coffee, 1991). Shleifer and Vishney (1986) also argue that increasingly shareholdings ownership can enhance the ability of its shareholders to monitor and influence the management more precisely in protecting its business activities. The higher the share ownership, the supervision of the majority shareholder will also be higher and therefore the value of the company will also increase (Smith, 1996).

In addition, the difference in the results can also be caused by the manager's role who do not consider the personal interest but the interests of shareholders and managers that can be aligned through the achievement of the organizational goals. If there is a difference of interest between the principal and the agent, then the agent will uphold the value of togetherness so that the corporate goals can be realized. This is suitable with the stewardship theory. In other words, Stewardship theory views management as a trustworthy to act at its best to realize the corporate interests such as enhancing corporate value (Donaldson and Davis 1989).
The testing of the relationship between ownership structure and firm value is still an issue that requires empirical testing, so the research is motivated to continue testing the relationship between concentrated ownership and firm value with a sample of firms in five Asian countries. The researcher conducted the study based on the explained argument. The first hypothesis in this study is as follows:

$\mathrm{H}_{1}$ : The concentrated ownership structure positively affects the firm value

\section{The Relationship between Ownership Structure, Analyst Following, and Firm Value}

Fan and Wong (2002) and Willekens et al. (2005) mention several reasons why good corporate governance qualities have an impact on analyst following, i.e. (1) analysts tend to choose firm characteristics that reveal more information in both financial and non-finance. This can lower the costs for analysts to dig and collect information; (2) firms that have good corporate governance mechanisms will be able to directly monitor the manager behavior, related to interests between managers and shareholders due to the separation of ownership, thereby reducing agency issues; (3) analysts prefer firms that have good governance mechanisms with better management perceptions that expect less effort to be made.

The testing results Lang et al. (2004) stated that analyst following is positively related to the firm value, especially the firms that have the potential to manipulate information and have poor corporate governance. The testing results of Yu (2009), Lang and Lundholm (1996) stated that the role of analyst following can increase the investor's knowledge, reduce asymmetric information risk and reduce capital cost. The researcher expects the interaction coefficient will be positive, which means to strengthen the relationship between concentrated ownership and firm value. Based on the argument explained, the second hypothesis in this study is as follows:

$\mathrm{H}_{2}$ : The positive influence of concentrated ownership structure to the firm value will be greater if the firm is followed by more analyst following.

\section{The Relationship between Investor Protection and Firm Value}

According to Chang et al. (2000), corporate governance mechanisms can be classified into two 
categories, namely (1) country-specific governance mechanisms such as investor protection, rule of law, and supervision by the capital market; (2) firm-specific internal mechanisms such as ownership structure, managerial incentive, and auditor selection.

The research results of La porta et al. (1998) suggests that governance at the corporate and governance levels at the country level tends to move together. Firms that have concentrated ownership (corporate level), tend to occur in countries with low investor protection (country level). This has an impact on the presence of centralized supervision. Gul and Qui (2002) argue that concentrated ownership tend to occur in countries with low investor protection. Internal parties of a firm have a tendency to influence the information and transactions, such as insider trading which, if unrestricted, will less consider the protection of minority shareholders' interests (La Porta, 1998). The investor protection is one of the external governance mechanisms at the country level.

There are still two different opinions regarding the influence of the firm domicile country (whether domiciled in the country with high investor protection or low investor protecttion) towards the contradictory firm values. The first opinion of La Porta et al. (1998) explains that in countries with low investor protection tend to have concentrated ownership so that blockholders have the ability to monitor agency activities and benefit from those controls. This phenomenon is defined as the cost-efficiency of monitoring by blockholders can increase the value of the company.

The second opinion states that concentrated share ownership tends to occur in countries with low investor protection. Claessens et al. (2002) report that firms in developing countries are dominated by concentrated ownership or assets resulting in conglomerations that incur high agency costs (Berger and Ofek 1995). Inefficient resource allocation (asset allocation to sustain survival) has an impact on declining firm values (Jensen and Meckling (1976) and Mansi and Reeb (2002).

Firms with a dispersed ownership structure are not much involved in their business activities because the dispersed ownership structure requires firms to be more open in every business activity. The distribution of share ownership tends to occur in countries with high investor protection (Leuz et al., 2003).
This research examines on how the relationship between the two mechanism groups of corporate governance with concentrated ownership (corporate level) with investor protection at the country level, that is testing whether the firm value that tend to have a concentrated ownership structure is influenced by the environment of investor protection of the domicile country of the company. Based on those arguments, the second hypothesis in this study is as follows:

$\mathrm{H}_{3}$ : The firm value will increase in firms that are domiciled in countries with low investor protection.

\section{RESEARCH METHOD}

\section{Data and Sample}

This research used Bloomberg and Bvd Osiris database as a source of firm financial data. The type of data used in this research is secondary data. The use of this database is chosen because it can meet the data requirements used for testing and other database access limitations. The observation year is planned in 2011-2013. These years were chosen because those are the year with the latest data update, and the firms in sample countries expected in this research are manufacturing firms in Asia consisting of China, Malaysia, South Korea, Taiwan, and Thailand. The selection of Asian firms as research samples is because most Asian firms have a concentrated ownership structure that have the potential for agency problems, more governance problems, and tend to be a country with low investor protection.

\section{Variable Measurement}

Variables measurement of this study are detailed in Table 1.

\section{Statistics Testing}

The concentrated ownership relationship, analyst following, and firm value, used the modified Multiple Regression statistics testing from Lang et al. (2004) that follows the Lang and Lundholm models, (1996) and Lang et al. (2003). Here is the regression equation to test hypotheses 1,2 , and 3 :

Tobin's $Q_{i}=\beta_{0}+\beta_{1}$ OWNCON $_{i t}+\beta_{2}$ ANFOLL $_{i t}+$ $\beta_{3} \mathrm{OWNCON}^{*}$ ANFOLL $+\beta_{\mathrm{i}} \mathrm{INVP}_{\mathrm{it}}$ 
Information :

$+\beta_{\mathrm{SIZE}}+\beta_{\mathrm{XXLIST}}+\beta_{\mathrm{ILEVERAGE}}+$ $\beta_{i}$ CAPEX $_{i}+\beta_{i}$ EASURP $_{i}+\varepsilon$

OWNCON = the proportion of the number of shares owned by the three largest shareholders in a firm $\mathrm{i}$ in year $\mathrm{t}$ (La Porta, 1998).

ANFOLL $=$ the number of analysts who forecast annual earnings of firm $i$ in year $\mathrm{t}$, listed in Bloomberg database.

INVP $=$ the number of five dimensions of investor protection measurement published by world economic forums.

SIZE = total natural logarithm of firm asset i in year $\mathrm{t}$.

XLIST $=$ dummy variable 1 if the company listings in the U.S Market and performs a financial statement reconciliation pursuant to U.S. GAAP, 0 otherwise, in company $\mathrm{i}$ in year $\mathrm{t}$.
$\mathrm{LEV}=$ ratio of firm total to asset total of firm i in year $\mathrm{t}$.

CAPEX = ratio of capital expenditures to total assets of firm $i$ in year $t$.

EASURP = the value of absolute, the difference in earnings per recent share with profit per share of the previous year divided to share price of company $i$ in year t.

$\varepsilon=$ standard error.

\section{Additional Testing}

The research that is related to the relationship between ownership structure and firm performance divides this relationship into 2 types, namely: linear and non-linear. Pedersen and Thomsen (1999) conducted testing using the assumption that there is a linear relationship between the concentrated ownership structure to

Table 1. Variables measurement

\begin{tabular}{|c|c|}
\hline Variable & Measurement \\
\hline Firm Value & $\begin{array}{l}\text { The Firm Value that is proxied with Tobin's Q, measured by: (Market Cap + Liabilities + } \\
\text { Preferred Equity + Minority Interest) / Total Assets. }\end{array}$ \\
\hline $\begin{array}{l}\text { Concentraded } \\
\text { ownership }\end{array}$ & $\begin{array}{l}\text { The concentrated ownership structure is measured with the proportion of the number of } \\
\text { shares owned by the five largest shareholders in a company's largest shareholder in a } \\
\text { company (Demsetz and Lehn, 1985). Nevertheless, not all shareholdings reach the five } \\
\text { largest owners. }\end{array}$ \\
\hline Analyts Following & $\begin{array}{l}\text { Analyst following is measured by the number of analysts who publish annual earnings } \\
\text { forecasts. }\end{array}$ \\
\hline Investor Protection & $\begin{array}{l}\text { The investor protection variable is measured with the investor protection index published } \\
\text { by the World Economic Forum that includes five dimensions: board independence, } \\
\text { enforcement of securities laws, protection of minority shareholder rights, enforcement of } \\
\text { accounting and auditing standards, and judicial independence. The value of investor } \\
\text { protection is the sum of the five dimensions (Houqe et al., 2012). This research } \\
\text { categorizes the level of investor protection into two, namely high and low level of investor } \\
\text { protection. The determination of high and low investor protection level is based on } \\
\text { median value, country which has investor protection value higher than median value is } \\
\text { categorized as country with high investor protection and vice versa. This research used the } \\
\text { median value instead of the average value because the median value is not affected by } \\
\text { investor protection values that is too high or too low, whereas the average value is usually } \\
\text { greatlv affected if there is value of investor protection which is too extreme. }\end{array}$ \\
\hline Control Variables & $\begin{array}{l}\text { Control variables used are: SIZE sign that is expected positive, XLIST sign that is } \\
\text { expected positive, CAPEX affects positively with the firm value. This research used } \\
\text { control variable according to research of McConnell and Sarvaes (1995) which states that } \\
\text { LEV have negative effect to the firm value. McConnell and Muscarella (1985) state that the } \\
\text { increase in capital expenditure has been responded positively to investors and therefore it } \\
\text { raises the value of shares. CAPEX has a positive effect on stock price volatility (Coles et } \\
\text { al., 2004). The other control variables related to the analyst following that are used } \\
\text { according to Lang and Lundholm (1996) research are EARNING SURPRISE which } \\
\text { negatively affects the analyst following. Lang and Lundholm (1996) state that the variable } \\
\text { earnings surprise is a deviation of expected earnings per share substation so that the analyst } \\
\text { must make a significant revision on the forecast. }\end{array}$ \\
\hline
\end{tabular}


the firm performance. In contrast, Morck et al. (1988) and McConnell and Servaes (1990) used testing model with the assumption of non-linear which is show that there is a non-linear relationship between managerial ownership and firm performance. The testing of linear or nonlinear relationship between concentrated ownership and firm performance can be seen from the impact of alignment and entrenchment effect.

Villalonga and Amit (2006) divide the agency costs into two types, namely: type I and type II. Type I occurs because there is a separation between the owner and the manager of the firm and the owners are not actively involved in managing the firm. The agents have the opportunity to not always act on the best interests of shareholders which is called managerial opportunism. Type II occurs when the owners are so dominant and become predators for the minority owners. This concentrated ownership creates owner opportunism when great control over transactions lies in their hands and can act more favorably to themselves (Morck et al., 1988). Type II is called entrenchment effect.

This research will test on the concentrated ownership level of how much, entrenchment effects tend to occur. Fama and Jensen (1983) state that if managerial ownership reaches more than $50 \%$, then there is full supervision. If there is full supervision, the majority may interfere with business activities and tend not to consider minorities. This research will test the various levels of concentrated ownership toward changes in Tobin's $Q$ value.

Based on the alignment argument, the higher concentrated ownership will improve the performance of the firm (Jensen and Meckling, 1976), while the argument entrenchment suggests that higher concentrated ownership will have a detrimental effect on firm performance (Morck et al., 1988).

\section{RESULT AND DISCUSSION}

The data were obtained from Bloomberg and Bvd Osiris database with observation years from 2011-2013. Table 2 illustrates the sample used in this research, such as manufacturing firms from five Asian countries consisting China, South Korea, Malaysia, Thailand, and Taiwan. The number of observations from China was 2,997 or $42.2 \%$ of all data, South Korea as many as 1,801 or $25.4 \%$ of all data, Taiwan as many as 1,337 or $18.8 \%$, Malaysia 773 or $10.9 \%$ and the least observation is Thailand with as many as 192 firms or $2.7 \%$ of the total observations in this research.

\section{Descriptive statistics}

Descriptive statistics can be used to view the deployment of the data to its central value (mean).

Table 2. Sample Selection by Country

\begin{tabular}{lcccccc}
\hline \multirow{2}{*}{ Country } & \multicolumn{3}{c}{ Year Observation } & \multirow{2}{*}{ Number of Observation } & \multirow{2}{*}{$\%$} \\
\cline { 2 - 4 } & $\mathbf{2 0 1 1}$ & $\mathbf{2 0 1 2}$ & $\mathbf{2 0 1 3}$ & & 2.997 & 42,2 \\
China & 975 & 1.115 & 907 & 1.801 & 25,4 \\
South Korea & 606 & 592 & 603 & 1,337 & 18,8 \\
Taiwan & 466 & 449 & 422 & 773 & 10,9 \\
Malaysia & 263 & 260 & 250 & 192 & 2,7 \\
Thailand & 68 & 59 & 65 & $\mathbf{7 . 1 0 0}$ & $\mathbf{1 0 0}$ \\
\hline Total & $\mathbf{2 . 3 7 8}$ & $\mathbf{2 . 4 7 5}$ & $\mathbf{2 . 2 4 7}$ & & \\
\hline
\end{tabular}

Table 3. Descriptive statistics

\begin{tabular}{lccccr}
\hline Variable & Min & Max & Mean & Median & StdDev \\
\hline Tobin'Q & 0,2625 & 3,7106 & 1,2019 & 1,1323 & 0,4140 \\
OWNCON & 0,16 & 99,63 & 46,2476 & 46,5100 & 19,855 \\
ANFOLL & 0 & 47 & 2,64 & 1.00 & 5,554 \\
INVP & 19 & 26,30 & 22,2559 & 21,300 & 2,3494 \\
SIZE_LN & 1,8573 & 12,8311 & 6,5653 & 6,5869 & 1,9049 \\
LEV & 0,0075 & 1,5613 & 0,4317 & 0,4360 & 0,198 \\
CAPEX & $-1,977$ & $-0,000$ & $-0,073$ & $-0,031$ & 1,672 \\
EASURP & 0,0001 & 32,955 & 0,5621 & 0,1557 & 1,8843 \\
XIST & 0 & $\mathrm{~N}=7.092$ & & & \\
\hline Total & 1 & $\mathrm{~N}=\mathbf{8}$ & & & $\mathbf{7 . 1 0 0}$ \\
\hline
\end{tabular}


One of the indicators of data dissemination can be seen in the standard deviation value. The lower the standard deviation value indicates that the data tends to have a value close to the average value of the data (see Table 3).

\section{Hypothesis Testing One: Effect of Ownership Concentration on Firm Value}

Before doing the regression for testing the two hypotheses, the researcher conducted the classical assumptions testing. Based on the classical assumption testing that has been performed and the calculation results, it shows that all the requirements have been fulfilled and therefore this reseach meet all the requirements of classical assumptions. The testing results of each classical assumption showed that the regression model did not experience multicollinearity, heteroscedasticity, autocorrelation, with normal distributing of standard error.

The first hypothesis $\left(\mathrm{H}_{1}\right)$ states that the concentrated ownership structure positively affects the firm value. This hypothesis leads to firms that have a higher concentrated ownership structure that the higher the firm value. Table 4 shows the results of hypothesis testing. The testing results show that the concentrated ownership structure has a significant positive effect on firm value, significant at p-value value $0.00(<0.01)$. Based on the testing results, the hypothesis one in this research which states that firms that have a higher concentrated owenership, have an effect on the firm value which is also supported.

These results support the opinion of Shleifer and Vishney (1986) who argue that an increasingly larger shareholding can increase the ability of its shareholders to monitor and influence the management more precisely in protecting its business activities. The higher the share ownership, the supervision of the majority shareholder will also

\footnotetext{
${ }^{1}$ Normality test was performed with Kolmogorov Smirnov test and normal probability plot of standardized residual Asymp. Sig. of 0.086. Multicollinearity testing is to test the correlation between independent variables as measured by Variance Inflanattion factor (VIF), and VIF value for all variables no more than 10 . Heteroscedasticity test using Glejser test with Prob value. ChiSquare of 1,000 . Autocorrelation test to ensure no correlation between variables by using Durbin-Watson test, with Durbin-Watson (DW) is 1.976.
}

be higher, so the value of the company will also increase (Smith, 1996).

Based on the testing results of all control variables, they show the appropriate direction except Xlist variable. The Xlist variable shows this unsuitable direction because of the average of firms listed in the New York Stock Exchange and reconciling financial statements in accordance with US. GAAP is less than those that are listed on the New York Stock Exchange but do not reconcile with US. GAAP.

Table 4. Results of Hypothesis Testing 1, 2, and 3

\begin{tabular}{|c|c|c|c|}
\hline \multicolumn{2}{|c|}{ Independent Variable } & $\begin{array}{l}\text { Expected } \\
\text { Sign }\end{array}$ & $\begin{array}{c}\text { Coefficient } \\
\text { (P-value) }\end{array}$ \\
\hline \multicolumn{2}{|l|}{ Constant } & & 1,074 \\
\hline \multicolumn{2}{|c|}{ OWNCON } & + & $\begin{array}{c}0,001 \\
(0,000)\end{array}$ \\
\hline \multicolumn{2}{|l|}{ ANFOLL } & + & $\begin{array}{c}0,006 \\
(0,000)\end{array}$ \\
\hline \multicolumn{2}{|c|}{ OWNCON*ANFOLL } & + & $\begin{array}{c}0,00001 \\
(0,700)\end{array}$ \\
\hline \multicolumn{2}{|l|}{ INVP } & - & $\begin{array}{c}-0,016 \\
(0,000)^{*}\end{array}$ \\
\hline \multicolumn{2}{|l|}{ SIZE_LN } & + & $\begin{array}{c}0,100 \\
(0,000)\end{array}$ \\
\hline \multicolumn{2}{|l|}{ LEV } & - & $\begin{array}{c}-0,645 \\
(0,000)^{*}\end{array}$ \\
\hline \multicolumn{2}{|l|}{ CAPEX } & - & $\begin{array}{c}-0,748 \\
\left(0,000^{*}\right)\end{array}$ \\
\hline \multicolumn{2}{|l|}{ EASURP } & - & $\begin{array}{c}-0,035 \\
(0,000)^{*}\end{array}$ \\
\hline \multicolumn{2}{|l|}{ XLIST } & + & $\begin{array}{c}-0,628 \\
(0,000))^{*}\end{array}$ \\
\hline \multicolumn{3}{|l|}{$\mathrm{R}^{2}$} & 0,400 \\
\hline \multicolumn{3}{|c|}{ Adjusted $\mathbf{R}^{2}$} & 0,399 \\
\hline \multicolumn{3}{|c|}{ Total Observation } & 7100 \\
\hline \multicolumn{4}{|c|}{ 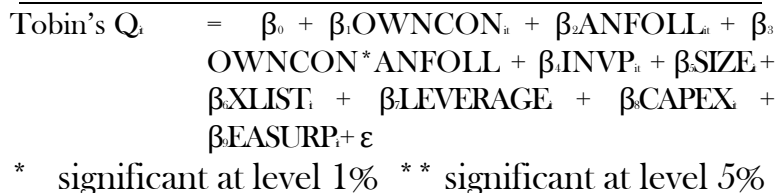 } \\
\hline
\end{tabular}

\section{The Results of Hypothesis Testing Two: Analyst Following as Moderate relationship between Concentrated Ownership and Value Company}

Hypothesis two states that the relationship between the concentrated ownership structure and the firm value gets stronger if the firm is followed by more analyst following. This leads to if the company has a highly concentrated ownership structure and analysts continue to analyze the firm, then the firm value will be higher. The influence of moderation of analyst following is done by testing the interaction between variable ownership 
concentration and analyst following. Related to that, the coefficient of regression result for the interaction variable (OWNCON * ANFOLL) is expected to be positive.

Table 4 shows that the coefficient of interaction between concentrated ownership with analyst following is not significant $(0,700>0,05)$. The results of this test indicate that analyst following is not a moderator of influence of concentration of ownership on firm value. Thus, the third hypothesis proposed in this research is not supported. However, the significant ANFOLL coefficient (0.006) implies that the analyst following variable is an independent variable that positively affects the firm value. Mouselli and Hussainey (2009) conducting firm testing that is listed in the London Stock Exchange stating that better corporate governance quality and more analytical amounts do not have a significant impact on raising corporate value. This gives an idea of the increase in corporate value is influenced by other factors.

\section{Result of Hypothesis Testing Three: The Environmental Effects of Investor Protection to Firm Value}

Hypotheses three that will be tested in this research is the effect of the investor protection environment to the firm value. Hypothesis three is said to be supported if the coefficient of the Investor Protection (INVP) variable is negatively significant. Table 4 shows the testing results that the Investor Protection (INVP) variable coefficient is significantly negative at p-value $0,000 \quad(<0.01)$. The results of this testing support the proposed hypothesis.

Highly concentrated ownership has consequences of minority shareholders. The need for investor protection will be higher if there is a minority shareholder (Boubaker and Labegorre, 2008). The protection of minority investors is weakened if the investor's ability to supervise the management is weak. La Porta et al. (1998) explains that in countries with low investor protection tends to have concentrated ownership, so that blockholders have the ability to monitor agency activities and benefit from those controls. to firm value show different results. Morck et al. (1988) and McConnell and Servaes (1990). This phenomenon is said that the cost-efficiency of monitoring by blockholders can increase the firm value.

\section{Additional Testing}

The additional testing in this research was conducted to examine how the effect of various levels of ownership is concentrated on changes in

Table 5. Regression Test Per Share Ownership Group

\begin{tabular}{|c|c|c|c|c|}
\hline Independent Variable & $\begin{array}{c}\text { Expected } \\
\text { Sign }\end{array}$ & $\begin{array}{c}\text { Coefficient of } \\
\text { Group Share } \\
\text { Ownership 0-20\% } \\
\text { (P-Value) }\end{array}$ & $\begin{array}{c}\text { Coefficient of Group } \\
\text { Share Ownership } \\
20-65 \% \\
\text { (P-Value) }\end{array}$ & $\begin{array}{c}\text { Coefficient of } \\
\text { Group Share } \\
\text { Ownership > 65\% } \\
\text { (P-Value) }\end{array}$ \\
\hline \multirow[t]{2}{*}{ Constant } & & 1,555 & 0,959 & 1,374 \\
\hline & & $(0,000)^{*}$ & $(0,000)^{*}$ & $(0,000)^{*}$ \\
\hline \multirow[t]{2}{*}{ OWNCON } & + & 0,002 & 0,002 & $-0,001$ \\
\hline & & $(0,268)$ & $(0,000)^{*}$ & $(0,652)$ \\
\hline \multirow[t]{2}{*}{ INVP } & + & $-0,003$ & $-0,003$ & $-0,021$ \\
\hline & & $(0,000)^{*}$ & $(0,000)^{*}$ & $(0,000)^{*}$ \\
\hline \multirow[t]{2}{*}{ SIZE_LN } & + & 0,043 & 0,043 & 0,109 \\
\hline & & $(0,000)^{*}$ & $\left(0,000^{*}\right)$ & $(0,000)^{*}$ \\
\hline \multirow[t]{2}{*}{ LEV } & - & $-0,339$ & $-0,339$ & $-0,870$ \\
\hline & & $(0,000)^{*}$ & $(0,000)^{*}$ & $(0,000)^{*}$ \\
\hline \multirow[t]{2}{*}{ CAPEX } & - & $-1,356$ & $-1,356$ & $-0,622$ \\
\hline & & $(0,000)^{*}$ & $(0,000)^{*}$ & $(0,000)^{*}$ \\
\hline \multirow[t]{2}{*}{ EASURP } & - & $-0,046$ & $-0,046$ & $-0,032$ \\
\hline & & $(0,002)^{*}$ & $(0,002)^{*}$ & $(0,000)^{*}$ \\
\hline \multirow[t]{2}{*}{ XLIST } & + & $-0,715$ & $-0,715$ & \\
\hline & & $(0,000)^{*}$ & $(0,000)^{*}$ & \\
\hline $\mathrm{R}^{2}$ & & 0,411 & 0,392 & 0,387 \\
\hline Adjusted $\mathrm{R}^{2}$ & & 0,405 & 0,391 & 0,384 \\
\hline Jumlah Observasi & & 805 & 4954 & 1.341 \\
\hline
\end{tabular}


the value of Tobin's $Q$. Testing related to the relationship of concentrated ownership structure conducted testing using non-linear assumptions. Testing of linear or non-linear relationships between concentrated ownership and firm performance can be viewed in terms of the impact of alignment and entrenchment effect. Based on the argument, this research will examine the nonlinear relationship between the concentrated ownership structure and the firm value. The grouping of the data is based on the characteristics of the sample, i.e. the percentage level of concentrated ownership. Since hypothesis two is not supported, this additional testing does not include the analyst following as a moderating variable. Regression test for all three groups can be seen in Table $5^{2}$.

Based on the result of share ownership group testing as much as $0-20 \%$, concentrated ownership variable has positive coefficient value with Asymp sig value. $0.268>0.005$ which means the influence of concentrated ownership on firm value is insignificant. The two-group regression testing shows that the concentrated ownership has a positive coefficient value with the Asymp.sig value. 0,000 $<0.005$ which means the influence of ownership is concentrated on significant firm value. If it is compared with the result of regression of group one which if $0-20 \%$ share ownership does not significantly affect the firm value, but if share ownership more than 20-65\% have significant effect to the firm value. 20-65\% ownership testing results provide evidence that alignment effects tend to occur. This is in line with the alignment argument which states that the higher concentrated ownership will improve the firm performance (Jensen and Meckling, 1976).

The result of regression test of group three is that share ownership more than $65 \%$ indicates that the ownership is not significant (p-value $=0,652$ > $0,005)$. This result does not support Fama and Jensen (1983) who state that if managerial ownership reaches more than $50 \%$ then there is full supervision and shareholders tend to take actions that benefit their own interests.

\footnotetext{
${ }^{2}$ All variables show appropriate sign except Xlist. This incompatible direction is due to the small sample of companies listed on NewYork Sock Exchange.
}

\section{CONCLUSION}

The first objective of this research is to examine whether the concentrated ownership structure has a positive effect on the firm value. The empirical test results provide evidence that the concentrated ownership structure has a positive effect on the firm value, which means that if the ownership structure is more concentrated then the value of the firm is higher. The second objective of the research is to examine whether the interaction between concentrated and analytical ownership had a positive effect on firm value. Although a firm has concentrated ownership but if the analyst continues to analyze the company, it will have a positive impact on the value of the firm because it gives more confidence to the investors in the decision making. The results of empirical testing prove that the interaction between concentrated ownership with analyst following does not affect the firm value. H2 testing results are not supported by the argument Lang et al. (2004) that states that analysts are less interested in firms with poor firm-level corporate governance, such as concentrated ownership.

The third objective of this research is to find out whether the protection of investors in the domicile country of the firms affect the firm value. The testing results provide empirical evidence that the firms domiciled in countries with low investor protection, tend to have a concentrated ownership structure. Although this research does not test cost-monitoring, it may be possible to establish monitoring by an efficient blockholder called cost efficiency of monitoring and therefore it can increase the value of the firm like the argument $\mathrm{La}$ Porta et al. (1998).

Additional testing were conducted to examine the effect of concentrated ownership on the firm value in terms of alignment and entrenchment effect. The testing results provide empirical evidence that if the concentrated ownership of up to $20 \%$ affects the value of the firm is not significant. Alignment effect tends to occur in stock ownership of more than $20 \%$ to $65 \%$. The effect of stock ownership is concentrated on the firm value if share ownership is more than $65 \%$ then the firm value will decrease. Entrenchment effect tends to occur if concentrated ownership is greater than $65 \%$. Fama and Jensen (1983) state that if managerial ownership reaches more than $50 \%$, then there is full supervision and shareholders tend to take actions that benefit their own 
interests. The testing results are consistent with the testing results conducted by Morck et al. (1988).

This research has some limitations regarding the use of research variables. The first limitation of this research is the measurement of investor protection variables that use the value of the World Economic Forum that will have the same investor protection score for each firm in the same country since the investor protection is a countrylevel variable. Further research can measure the investor protection by using four dimensions, which is proxied with the disclosure requirement (DR), standard liability (LS), anti director right (ADR), and public enforcement (PE) that are proposed by LaPorta et al. (1998, 2006).

The second limitation of this research is the measurement of corporate governance variables that are only proxied with the variable of concentrated ownership structure. Further research can use other corporate governance dimensions such as the Corporate Governance Index based on Credit Lyonnais Securities Asia (CSLA) (Klapper and Love, 2004). The third limitation is related to the measurement of analyst following variables. The available database are limited and therefore the measurement of analyst following variables has not been presented better. Therefore, the further research is recommended to be able to use a more complete database presenting data analyst following such as I / B / E / S.

\section{REFRENCES}

Barniv, R., M. Myring and W. Thomas. 2005. The association between the legal and financial reporting environments and forecast performance of individual analysts. Contemporary Accounting Research, 22, 727-758.

Berger P. and E. Ofek. 1995. Diversification"s effect on firm value. Journal of Financial Economics, 37(1), 39-65.

Boubaker, S. and F. Labe'gorre. 2007. Ownership structure, corporate governance and analyst Following:A study of French listed firms. Journal of Banking \& Finance, 32, 961-976

Chang, J., T. Khanna and K. Palepu. 2000. Analyst activity around the world Working Paper, Harvard Business School.

Cheng, M. and K. R. Subramanyam. 2008. Analyst following and credit ratings.
Contemporary Accounting Research, 25 (4), 1007-1044.

Claessens, S., S. Djankov, J.P.H. Fan, and H. P. Lang. 2000. The Separation of Ownership and Control in East Asian Coorporation, Journal of Financial Economics, 58, 81-112.

Claessens, S., S Djankov, J.P.H. Fan and H. P. Lang. 2002. Disentangling the incentive and Entrenchment Effects Of large Shareholdings. Journal of Finance, 57, 2741-2771

Coffee, J. C. 1991. Liquidity Versus Control: The Institutional Investor as Corporate Monitor. Columbia Law Review, 91 (6), 1277-1368.

Coles, J. L., N.D. Daniel and L. Neveen. 2004. Managerial Incentives and Risk-Taking. Journal of financial Economics, 79 (2), 431468.

Demsetz, H. and K. Lehn. 1985. The structure of corporate ownership: Causes and consequences. Journal of Political Economy, 93, 1155-1177.

Fama, E. F. and M. C. Jensen. 1983. Separation of Ownership and Control. The Journal of Law \& Economics, 26 (2), 301-325.

Fan, J., and T. Wong. 2002. Corporate ownership structure and the informativeness of accounting earnings in East Asia. Journal of Accounting and Economics, 33, 401-425.

Gul, F. and H. Qiu. 2002. Legal protection, corporate governance and information asymmetry in emerging financial markets. Working paper, City University of Hong Kong.

Healy, P. and K. Palepu. 2001. Information asymmetry, corporate disclosure, and thecapital markets: a review of the empirical disclosure literature. Journal of Accounting and Economics, 31 (1), 405-440.

Houqe, M. N., T. V. Zijl, K. Dunstan, and A. K. M. W. Karim. 2012. The Effect of IFRS Adoption and Investor Protection on Earnings Quality Around the World. The International Journal of Accounting, 47, 333-355.

Jensen, M.C, and W. H. Meckling. 1976. Theory of the Firm; Managerial Behavior, Agency Cost and Ownweship Structure. Journal of Financial Economics, 3, 305-360

Klapper, L., and I. Love. 2004. Corporate governance, investor protection, and performance in emerging markets. Journal of Corporate Finance, 703-728.

Lang, M. H., K. V. Lins, and D. P. Miller. 2004. Concentrated control, analyst following and 
valuation: do analysts matter most when investors are protected least?'. Journal of Accounting Research, 42, 589-622.

Lang, M. H. and R. J. Lundholm. 1996. Corporate disclosure policy and analyst behavior. Accounting review, 467-492.

La Porta, R., F. Lopez-de-Silanes, A. Shleifer, and R. W. Vishny. 1998. Law and Finance. Journal of Political Economy, 106 (6), 1113-1155.

La Porta, R., F. Lopez-de-Silanes, A. Shleifer, and R. Vishny. 2000. Investor protection and corporate governance. Journal of Financial Economics, 58, 3-27.

Lemmon, M. L. and K. V. Lins. 2003. Ownership structure, corporate governance, and firm value: Evidence from the East Asian financial crisis. The journal of finance, 58 (4), 1445-1468.

Lang, M., K. Lins, and D. Miller. 2003. ADRs, analysts, and accuracy: Does cross listing in the United States improve a firm's information environment and increase market value?. Journal of Accounting Research, 41 (2), 317-345.

Lang, M., K. Lins, and D. Miller. 2004. Concentrated control, analyst following and valuation: Do analysts matter most when investors are protected least?. Journal of Accounting Research, 42 (3), 589-622.

Mouselli, S. and K. Hussainey. 2014. Corporate governance, analyst following and firm value. Corporate Governance, 14 (4), 453466.

Morck, R., A. Shleifer, and R. W. Vishny. 1988. Management Ownership andMarket Valuation: An Empirical Analysis. Journal of Financial Economics, 20, 293-315.

Pedersen, T. and S. Thomsen. 1997. European patterns of Corporate Ownership: A Twelve-Country Study. Journal of International Business Studies, 28 (4), 759-778.

Pedersen, T. and S. Thomsen. 1999. Economic and systemic explanations of ownership concentration among Europe's largest companies. International Journal of the Economics of Business, 6 (3), 367-381.

Shleifer, A. dan R. W. Vishny. 1986. Large Shareholders and Corporate Control. Journal of Political Economy, 94, 461-488.

Smith, P. M. 1996. Shareholder Activism by Institutional Investors: Evidence from CalPERS. The Journal of Finance, 51 (1), 227-252
Villalonga, B. and R. Amit. 2006. How do family ownership, control and management affect firm value?. Journal of financial Economics, 80 (2), 385-417.

Shah, S. Z. A. and Z. Hussain. 2012. Impact of ownership structure on firm performance evidence from non-financial listed companies at Karachi Stock Exchange. International Research Journal of Finance and Economics, 84.

Yu, M. 2009. Analyst following and corporate governance: emerging-market evidence. Accounting Research Journal, 23 (1), 69-93. 